\title{
Copepod fauna (Calanoida and Cyclopoida) in small ponds of the Pollino National Park (South Italy), with notes on seasonality and biometry of species
}

\author{
Genuario BELMONTE*, Giuseppe ALFONSO and Salvatore MOSCATELLO \\ Laboratory of Zoogeography and Fauna, Di.S.Te.B.A., University of Lecce, I-73100 Lecce, Italy \\ *e-mail corresponding author: genuario.belmonte@unile.it
}

\begin{abstract}
The plankton copepod fauna of the Pollino National Park (South Italy) were studied for the first time. Plankton samples were collected from 5 ponds, and 2 of these ponds were sampled monthly for one year to study species' seasonality. The length of adult specimens was measured to investigate body size variability. The variation of egg number in female egg sacs was evaluated for 2 species. Copepods were present in the plankton of the 5 ponds with a total of 10 species (2 Calanoida, 8 Cyclopoida), belonging to different genera. The 2 ponds which were studied in detail gave 7 and 8 species, respectively (only 1 calanoid per pond). Three species were exclusive to a single pond; only 1 species (the cyclopoid Eucyclops serrulatus) was found in all the 5 ponds. One calanoid (Arctodiaptomus kerkyrensis) and one cyclopoid (Tropocyclops prasinus) were perennial, with adults present in all the samples collected from the pond they inhabited. The second calanoid (Mixodiaptomus lilljeborgi) was found also under the snow-ice cover of the pond during winter, but was absent from summer-autumn samples. The adults of the remaining Cyclopoida species, in contrast, were generally absent from winter samples. All of the species showed adult females larger than males. Winter-spring adults were generally larger than the summer-autumn ones. The clutch size was directly correlated with the female body size. In a comparison between the 2 Calanoida, the one that inhabits the most stable pond (i.e. the pond with the smallest water-volume variation) showed many generations per year, and the smallest variation in clutch size and body size among generations. In the case of $\mathrm{E}$. serrulatus, which populated both of the ponds, the body size of the population of the unstable pond showed a wider variability than that of the stable pond.
\end{abstract}

Key words: Copepoda, Pollino National Park, body size, seasonality, freshwater ponds

\section{INTRODUCTION}

Calanoida and Cyclopoida of the Italian fauna (a total of 114 species, according to Stoch, 2005a) are well known in large lakes and many ponds in the Alps, northern and central Apennines, Sardinia and Sicily. On the other hand, there has been little study of the ponds in the southern Italian peninsula, where large lakes do not exist. This has resulted in very scant knowledge of the copepod fauna from a region of about $62,000 \mathrm{~km}^{2}$.

Calanoida are generally present in less than $50 \%$ of the water bodies studied and it is rare for more than 1 species to co-exist in the same basin [for studies which summarized data from many Italian water bodies, see Stella (1970), Mastrantuono (1991), Naselli-Flores et al. (1998), Jersabeck et al. (2001), Manca \& Armiraglio (2002) and Tavernini et al. (2003)]. Cyclopoida are generally present in all the water bodies investigated, with multi-species commonly co-existing in each site. However, co-existence for co-generic species has only rarely been reported for this taxon (e.g., Margaritora et al. 1981; Mastrantuono 1991; Ruggiero et al. 2004). On the other hand, Calanoida seem to prevail in puddles and/or high altitude ponds (Gauthier 1928; Jersabeck et al. 2001; Marrone \& Naselli-Flores 2004).

In Italy, the number of species of plankton copepods co-existing in the same pond generally never exceeds 5 species, and it is lower than that of Cladocera and Rotifera in the same basin (e.g., Margaritora \& Usai 1983; Margaritora 1990; Rossi et al. 1992; Margaritora $\&$ Roberti 1995). These numbers are considered important and, although caution has been repeatedly recommended (Hutchinson 1967; Ravera 1996; Jeppesen et al. 2000), the relative abundance of Copepoda/Cladocera species, as well as that of Cyclopoida/Calanoida has repeatedly been proposed as an indicator of environmental quality (Patalas 1972; McNaugh 1975; Karjalainen et al. 1999; Jersabeck et al. 2001; Margaritora et al. 2003).

In temperate regions, copepods adapt themselves to periodic extremely harsh conditions (even the complete drying up of some ponds) with the evolution of a rest stage (Santer 1998), [see Alexeev (1990) and WilliamsHowze (1997) for a wide view on freshwater crustacean dormancy] which is maintained even in permanent lakes (Elster 1936, 1954) and/or by perennial populations (e.g., Tavernini et al. 2003). Less intense variations of the environment are generally faced using modifications in life history traits (developmental rate, number of eggs produced) which, in turn, are correlated with morphology (e.g., body size). It is well-known that copepod body size is often variable in successive generations [as first reported by Adler \& Jaspersen (1920)], due to variations in environmental conditions during the growth phase [see Mauchline (1998) for a review]. Generally, among all aquatic invertebrates, the body size 


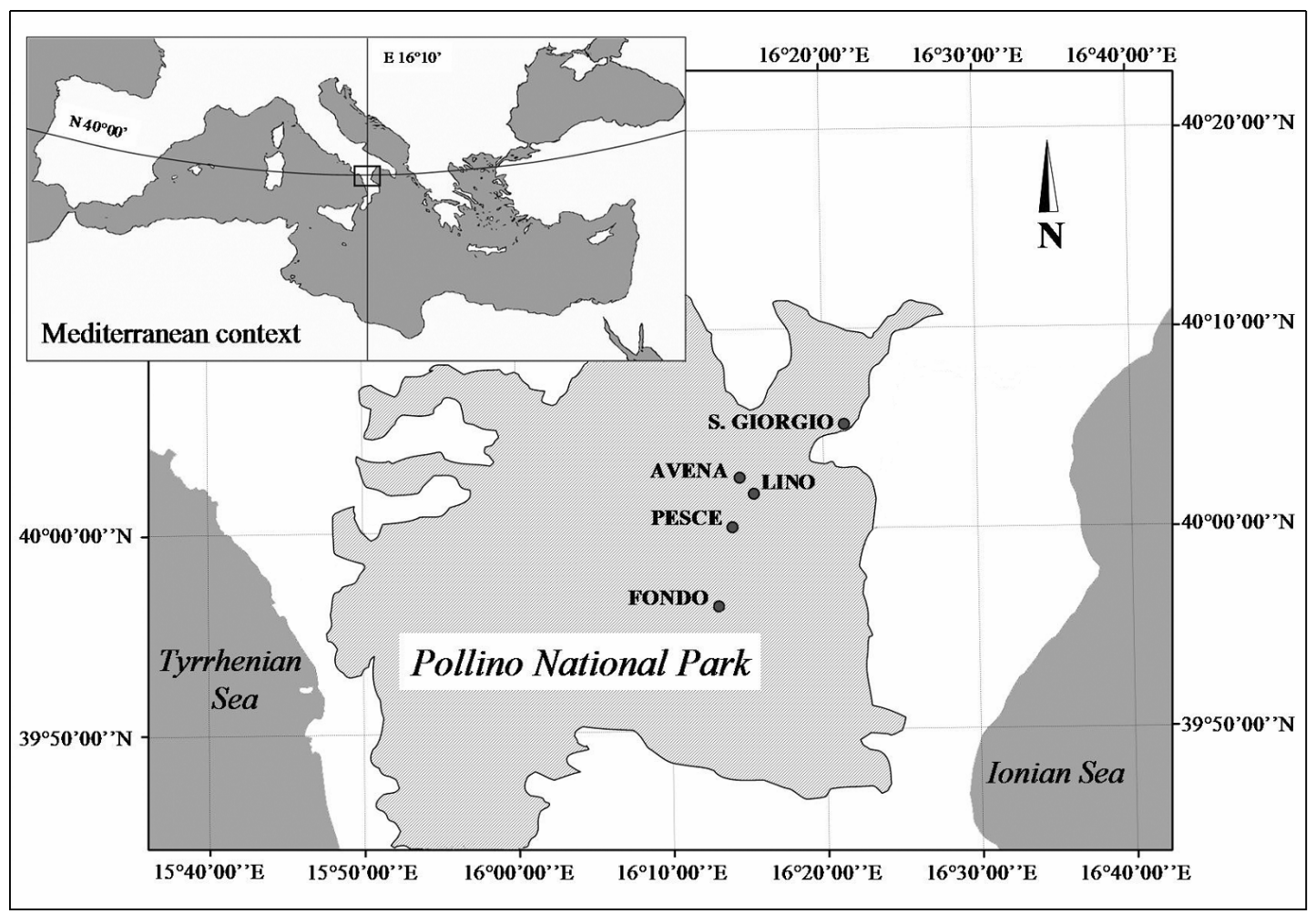

Fig. 1. Geographical location of the Pollino National Park and the 5 ponds studied.

of adults is inversely correlated with the temperature at which growth occurs (Atkinson 1994; Atkinson \& Sibly 1997), because catabolism has a higher thermal coefficient than anabolism (Von Bertalanffy 1960). Among Italian freshwater copepods, an evident seasonal size variation has already been reported (Tonolli 1947; Stella 1961; Mastrantuono 1981).

Clutch size is also variable, and Hutchinson (1951) proposed that such variation among Calanoida is related to food-supply rather than to physical environment. He found the same clutch-size variations in Cyclopoida and pelagic Cladocera. Ravera \& Tonolli (1956) reported that the clutch size of some Calanoida could be related to environmental features, such as the ratio "drainage basin/lake surface", in high altitude lakes. Rossetti et al. (1995) found a significant inverse correlation between clutch size and ageing of females, which also corresponded with an increasing presence of a parasitic fungus in Eudiaptomus intermedius.

The aim of the present study is to contribute to the filling of the gap in the knowledge of the Italian copepod fauna, through the first investigation on the Pollino National Park, an otherwise well known biodiversity hot spot (Stoch 2005b). Certain features (seasonality, body size, and clutch size) have been taken into consideration to give a description of the phenotype variability.

\section{METHODS}

A series of surveys was conducted (November 2002, January, and March 2003) on 4 water bodies in the northern portion of the Pollino National Park (Fig. 1) to obtain a preliminary fauna list. An additional pond (Lago del Lino) was visited in June 2006 to complete the data set for the same area.

The included water bodies were (from north to south):

- San Giorgio (San Giorgio Lucano), $370 \mathrm{~m}$ above sea level; 4005'24" N; $16^{\circ} 22^{\prime} 09^{\prime \prime}$ E. Approximate size: $120 \times 50 \mathrm{~m}$; depth: $2 \mathrm{~m}$. This pond sits in partially loaming soils covered by a tight shrub vegetation and is obstructed by a landslide. The pond is probably of recent origin, as it is absent from official maps.

- Avena (Francavilla in Sinni), $507 \mathrm{~m}$ above sea level; $40^{\circ} 03^{\prime} 00^{\prime \prime} \mathrm{N} ; 16^{\circ} 14^{\prime} 45^{\prime \prime}$ E. Approximate size: $105 \times 45 \mathrm{~m}$, depth: $<3 \mathrm{~m}$, with major axis oriented NE-SW. Perennial, with annual level oscillations of about $1 \mathrm{~m}$. The pond is surrounded by an oak wood (Quercus cerris) and presents a wide band of reedy fen (Typha sp.) along the SW side. At least 3 species of fish (carp, tench, goldfish) live in the pond.

- Lino (San Costantino Albanese), $740 \mathrm{~m}$ above sea level; 4002'05" N; $16^{\circ} 15^{\prime} 35^{\prime \prime}$ E. Approximate size: $100 \times 55 \mathrm{~m}$; depth $2,5 \mathrm{~m}$, with major axis oriented $\mathrm{N}$ S. Perennial, with level oscillations of about $1 \mathrm{~m}$. The pond is in a depression of a landslide with only a scattered distribution of willows and ash-trees.

- Grande (or Lake Pesce) (Francavilla in Sinni), 1190 $\mathrm{m}$ above the sea level; 4000'32" N; 16 $133^{\prime} 29^{\prime \prime} \mathrm{E}$. Size varies according to the filling conditions, in 
Tab. 1. Distribution of the copepod species found in the studied ponds.

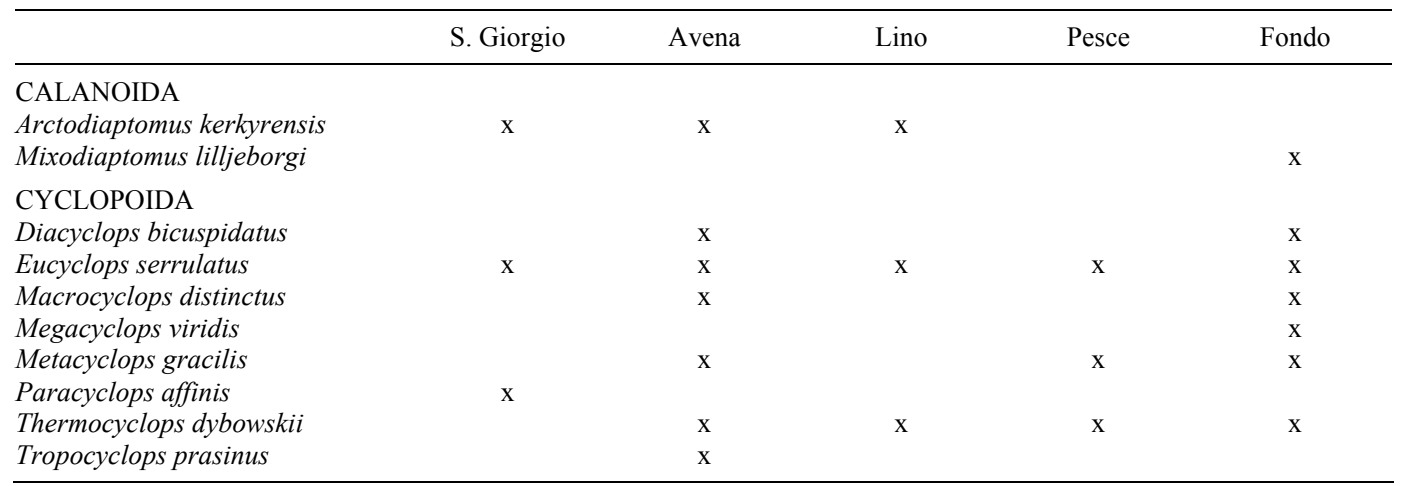

average $190 \times 85 \mathrm{~m}$; depth $<1 \mathrm{~m}$, with major axis oriented SE-NW. The shallow brim on the SE ridge allows the basin to overflow. The maximum depth is less than $50 \mathrm{~cm}$ during late summer. The pond is situated in a beech forest, is not exposed to sun, and is probably of recent origin, because it is absent from official maps. Goldfish live in the pond.

- Fondo (Terranova del Pollino) $1510 \mathrm{~m}$ above sea level; 39 $56^{\prime} 43^{\prime \prime} \mathrm{N} ; 16^{\circ} 13^{\prime} 36^{\prime \prime}$ E. Average size of about $50 \times 30 \mathrm{~m}$; depth usually $<1.5 \mathrm{~m}$, but infrequently up to $3.5 \mathrm{~m}$. The major axis is oriented N-S. The water level shows up to $3 \mathrm{~m}$ of variation, with consequent heavy modifications in volume and surface area. In particularly dry years, the pond completely dries up in the late summer, and hence could be classified as temporary. It is obstructed by an ancient landslide, in a small dolina which has its brim at $1520 \mathrm{~m}$ (hence the pond has nosurface outlets). The area which hosts the pond is a open beech forest. The pond is fish free.

All of the zooplankton samples were collected by horizontal towing of two plankton nets, with a mouth diameter of $24 \mathrm{~cm}$, but with different mesh sizes (200 and $50 \mu \mathrm{m}$ ) for the collection of representatives of different sized copepods.

We studied the seasonality of copepod populations in two of the ponds (Avena, AVE; and Fondo, FON), selected for their accessibility. Samples were collected monthly from May 2003 to May 2004, with the exception of August 2003. At each sample collection, the water temperature was measured. Samples were fixed in situ with neutralised $(\mathrm{pH}$ 7.3) formalin at a final concentration of $4 \%$. In FON, the sample collections of January, February, and March 2004 were carried out by vertical towing of the plankton net through a circular hole in the ice.

Samples were analysed under a compound microscope (magnifications $31.2 \times, 125 \times$ and $250 \times$ ) and species identification was performed on the adults according to Dussart $(1967,1968,1989)$, Ranga Reddy (1994) and Stella (1984).

The body length of 12 to 20 adult specimens (the number depending from the availability) of each sex of each species were measured in each sample. The body size was obtained by measuring (with an ocular micrometer) the distance from the head to the extremity of the left furcal ramus. The statistical analysis of size only included those species whose adults were present in at least $2 / 3$ of the available samples, i. e. 8 of the 12 samples for each pond.

For Calanoida, from 10 to 30 egg sacs (either still attached to the female genital segment, or found detached) of the same species were dissected in each sample to obtain the number of eggs female ${ }^{-1}$ (clutch size).

Average sizes of males and females of each species were compared with a $t$-test. Linear regression analysis was carried out to evaluate the existing correlations between the size or clutch size and temperature. For these comparisons, specimens from preliminary samples (January and March 2003) were also utilized. A simple variability index [(max value - min value) (average value)-1\%] was calculated to compare the range of variation in the biotic measures (size and clutch size) of different populations (of the same or different species) collected from different ponds.

\section{RESULTS}

A total of 10 species of Copepoda were found, belonging to 10 different genera (Tab. 1). Calanoida were represented by 2 species (Arctodiaptomus kerkyrensis, Mixodiaptomus lilljeborgi), and Cyclopoida by 8 (Diacyclops bicuspidatus, Eucyclops serrulatus, Macrocyclops distinctus, Megacyclops viridis, Metacyclops gracilis, Paracyclops affinis, Thermocyclops dybowskii, Tropocyclops prasinus). Only 3 species were exclusive to a single pond ( $P$. affinis in S. Giorgio; $M$. lilljeborgi, and $M$. viridis, in FON). On the other side, only 1 species, E. serrulatus, was present in all 5 ponds.

The two ponds which were repeatedly sampled for one year (AVE and FON), hosted 7 and 8 species, respectively (1 calanoid in both cases).

In $\mathrm{AVE}$, the water temperature ranged from 8.0 (in March) to $30{ }^{\circ} \mathrm{C}$ (in July). The pond size reached its maximum in March (maximum depth, $2.5 \mathrm{~m}$ ), and its minimum in September (maximum depth, $1.5 \mathrm{~m}$ ). 
Tab. 2. Copepod species found in the ponds investigated, with statistical comparison between male and female bodysizes. The total number of measured specimens $(\mathrm{N})$ derives from all the ponds interested by their presence. Comparisons were conduced exclusively on paired data (i.e. only where both sexes were represented in the same sample). $P$, level of probability.

\begin{tabular}{|c|c|c|c|c|c|c|c|c|c|c|c|}
\hline \multirow{3}{*}{ Species } & \multirow{3}{*}{ Pond } & \multicolumn{4}{|c|}{ Males } & \multicolumn{4}{|c|}{ Females } & \multirow{3}{*}{$t$ Student } & \multirow{3}{*}{$P$} \\
\hline & & \multirow[t]{2}{*}{$\mathrm{N}$} & \multicolumn{3}{|c|}{ Body size $(\mu \mathrm{m})$} & \multirow[t]{2}{*}{$\mathrm{N}$} & \multicolumn{3}{|c|}{ Body size $(\mu \mathrm{m})$} & & \\
\hline & & & $\min$. & $\max$. & ave. & & $\min$. & $\max$. & ave. & & \\
\hline M. lilljeborgi & FON & 182 & 1375.5 & 2060.0 & 1764.7 & 188 & 1490.0 & 2488.0 & 2070.7 & -2.688 & $<0.05$ \\
\hline D. bicuspidatus & AVE; FON & 28 & 714.0 & 981.8 & 878.7 & 37 & 935.3 & 1281.8 & 1108.9 & -6.176 & $<0.001$ \\
\hline E. serrulatus & AVE; FON & 59 & 656.9 & 1036.4 & 821.5 & 112 & 807.0 & 1363.6 & 1083.9 & -5.614 & $<0.001$ \\
\hline M. gracilis & AVE; FON & 34 & 471.2 & 614.0 & 547.8 & 125 & 621.0 & 756.8 & 697.8 & - & - \\
\hline P. affinis & S. Giorgio & 4 & 695.2 & 748.0 & 743.6 & 3 & 862.4 & 976.8 & 912.3 & - & - \\
\hline T. dybowskii & AVE; FON & 16 & 428.4 & 649.7 & 552.0 & 55 & 593.2 & 943.1 & 714.0 & -0.561 & $<0.001$ \\
\hline T. prasinus & AVE & 86 & 506.9 & 685.4 & 588.3 & 190 & 643.0 & 892.5 & 768.1 & -8.290 & $<0.001$ \\
\hline
\end{tabular}
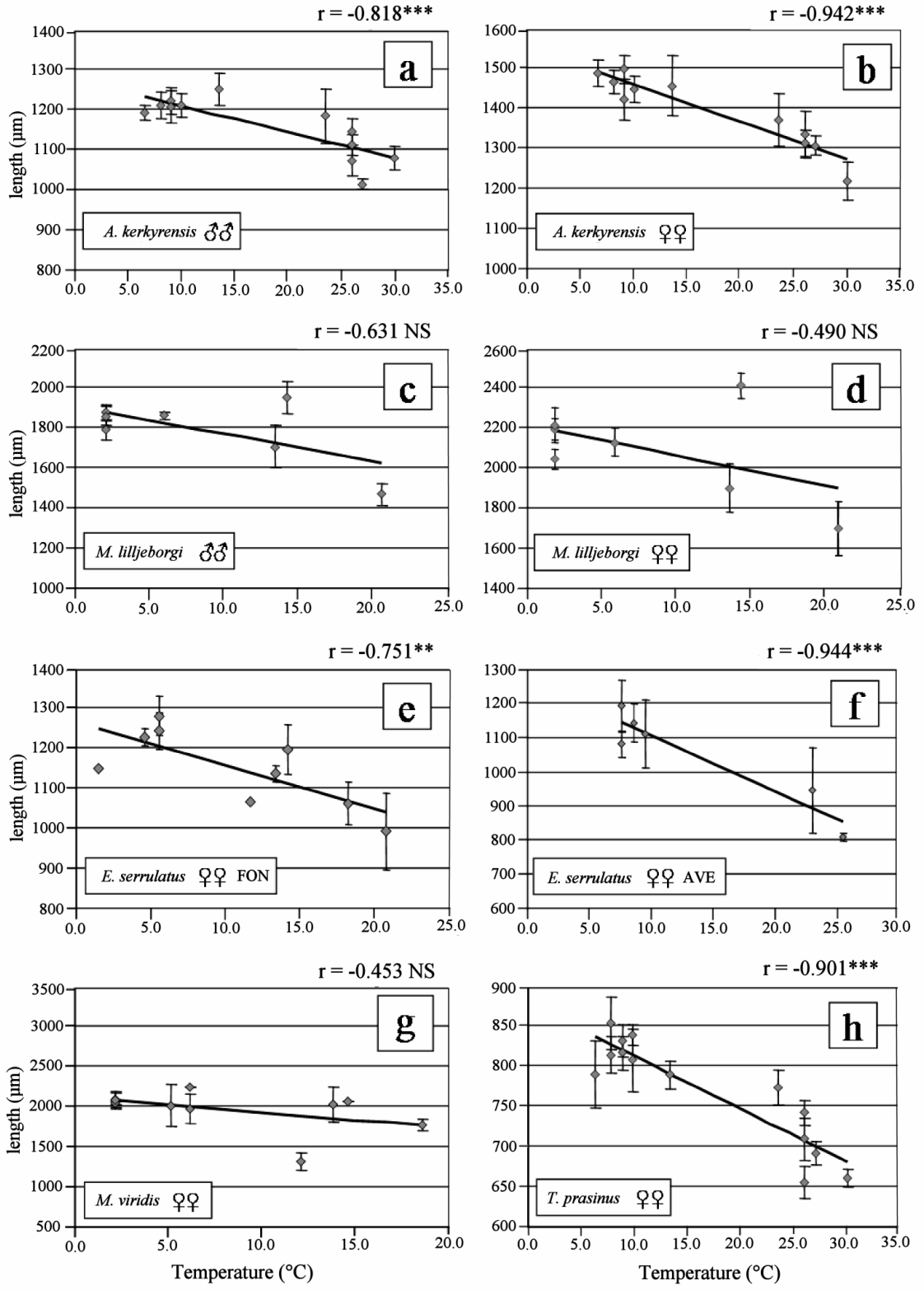

Fig. 2. Linear correlation between body length and water temperature in 5 copepod species. NS $=$ Not Significant; $\left({ }^{*}\right)=P<0.05 ;(* *)$ $=P<0.01 ;(* * *)=P<0.001$. 
On an annual basis, the zooplankton was composed, apart from the 7 Copepoda species, of 64 other taxa (data not published).

In FON the water temperature ranged from 1.0 (under the ice cover, in March) to $21.0{ }^{\circ} \mathrm{C}$ (in July). The pond size reached its maximum in May 2003 (maximum depth, $3.5 \mathrm{~m}$ ) and reduced to its minimum in September (maximum depth, $0.35 \mathrm{~m}$ ). Active copepods were also found during winter (January - March 2004) in the water, under the ice-snow cover. On an annual basis, the zooplankton was composed, apart from the 8 cited copepods, of 57 other taxa (data not published). All the zooplankton taxa were seasonal (none was found in all of the samples collected).

In the ponds repeatedly sampled, only two species (A. kerkyrensis, T. prasinus) were perennial (i.e., they were present in all the samples in AVE). Among the other species, $M$. lilljeborgi adults were absent from September to November samples, with few males in December, and females were present only after January. Cyclopoida adults were generally absent in autumnwinter months, although not continuously.
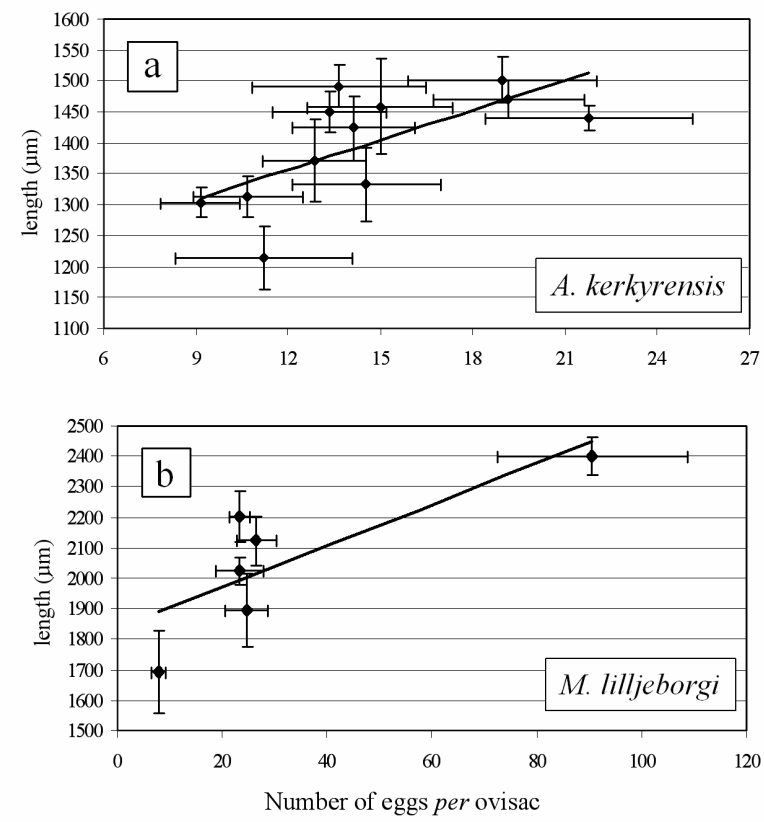

Fig. 3. Linear correlation between body length and clutch size of A. kerkyrensis (a) and M. lilljeborgi (b). Average of each sample/date were compared. $\left({ }^{*}\right)=P<0.05 ;(* *)=P<0.01$.

Among adult copepods, males were smaller than females in every species. However, due to the need for homogenous data from the same pond/population and/or season, a statistical comparison was only possible for 6 species (A. kerkyrensis, M. lilljeborgi, D. bicuspidatus, E. serrulatus, T. dybowskii, T. prasinus) (Tab. 2). Adults were generally larger in winter-spring and smaller in summer-autumn, but a statistically valid inverse correlation with the water temperature was found only in both sexes of $A$. kerkyrensis, females $E$. serrulatus (both ponds), and females T. prasinus (Fig. 2).

The clutch size was directly correlated to the female's body size in A. kerkyrensis (Fig. 3a) and $M$. lilljeborgi (Fig. 3b).

The adult body size of the FON population of E. serrulatus varied more than that of the AVE population. This result was also apparent in the copepod assemblage as a whole. In fact, FON copepods generally showed a size variability wider than that of AVE copepods, regardless of species (Tab. 3).

Tab. 3. Values of the "variability index" [(max value - min value) (average value $)^{-1} \%$ for species from lakes AVE and FON. The value considered was the body length (for adult males and females), and the clutch size (n. eggs egg $\mathrm{sac}^{-1}$ ).

\begin{tabular}{|c|c|c|c|c|}
\hline Pond & Species & $\hat{\partial} \widehat{\partial}$ & 우우 & Eggs \\
\hline \multirow{5}{*}{$\sum_{4}^{5}$} & A. kerkyrensis & 29.4 & 33.4 & 80.0 \\
\hline & E. serrulatus & 23.2 & 45.1 & - \\
\hline & M. gracilis & 38.6 & 30. & - \\
\hline & T. dybowskii & 41.7 & 49.5 & - \\
\hline & T. prasinus & 43.7 & 34.2 & - \\
\hline \multirow{4}{*}{ Zू } & M. lilljeborgi & 38.7 & 48.2 & 298.8 \\
\hline & D. bicuspidatus & 25.2 & 26.2 & - \\
\hline & E. serrulatus & 44.9 & 54.2 & - \\
\hline & M. viridis & 37.3 & 61.4 & - \\
\hline
\end{tabular}

\section{DISCUSSION}

The number of copepod species found in each of the two ponds studied in detail was unusually high [e.g., Margaritora \& Usai (1983), Margaritora (1990), Rossi et al. (1992) and Margaritora \& Roberti (1995) for similar ponds in Italy]. In addition, copepods were accompanied by a well diversified zooplankton community (more than 60 taxa in each site) which suggests a generally high biodiversity for Pollino ponds.

Together with species common to the Italian territory, the Pollino copepod fauna includes Arctodiaptomus kerkyrensis (first reported in Italy from the Pollino by Licchelli et al. 2003) and other species (Macrocyclops distinctus, Metacyclops gracilis, Paracyclops affinis) which have only been recorded in the southern Italian Peninsula. Arctodiaptomus kerkyrensis is well represented (it was collected in 3 of 5 ponds) and in AVE its adults were recorded in every month of the year. This fact does not exclude the possibility that resting eggs could be produced [as found by Tavernini et al. (2003) in Eudiaptomus intermedius], but it excludes the existence of a single generation per year as proposed by Ranga Reddy (1994). In fact, the different body sizes measured in different months testifies to the presence of adults which did not grow together (i.e. they were not of the same cohort).

With respect to the seasonality of species, we can only note that the 2 Calanoida ( 1 perennial, 1 estivating) differed from the Cyclopoida (mainly overwintering). 
The estivation of $M$. lilljeborgi was witnessed by the absence of adults from September until December (when only a single male was recorded, females being present from January onwards). Developmental stages of Calanoida are easily distinguishable from those of Cyclopoida, and in Autumn months the progressive presence of calanoid nauplii (from September onwards), and copepodids (from November onwards) was easily recorded in FON, where they should represent the recruits from the resting eggs of the preceding generation. A similar timing in the presence of developmental stages was not recognized among Cyclopoida. Due to the similarity of the early developmental stages, the contemporaneous presence of more than one species did not allow a correct interpretation of the demographic development of single populations. In addition, Cyclopoida rest as dormant copepodids or even as adults (Alexeev 1990), hence they need less time to enter the plankton (and to be sampled) following dormancy.

The abundance of the 2 Calanoida allowed us to study precisely the variability in adult body-size. In $M$. lilljeborgi body size was not significantly correlated with the temperature of the water. This was probably due to the survival of the large sized winter generation until May-June when they were collected. In fact, the pond (FON) was covered by ice and snow until the end of April 2003 (a visit in the first days of May allowed us to record the fresh melting iceand snow, with the water level risen by about $3 \mathrm{~m}$ ), with a consequent lengthening of the copepod under-ice generation. Rossetti et al. (1995) confirm that an ice-covered pond is not deprived of active plankton. The large adults from the under ice generation of FON rapidly disappeared in June, and were completely replaced by a "warm water generation" whose adults appeared notably smaller in the sample at the beginning of July. The rapidity of growth (favoured by high temperature) of the spring-summer generation is probably fundamental for the persistence of Calanoida (obliged to become adults for the production of eggs which must estivate) in environments which possibly dry up in late summer (as FON did in August 2002). The result is the smallest possible body size in early summer adults. In the second calanoid (A. kerkyrensis), living in a permanent pond, an inverse correlation of adult body sizes with temperature was evident. In the case of E. serrulatus (with a population per pond), the FON individuals, living at an average temperature lower than that of AVE, were clearly larger than the AVE ones. In this case, however, we cannot exclude possible effects caused by the presence of fish in AVE, as demonstrated by Galbraith (1966) for cladocerans, and detailed studies should be conducted to evaluate the role of both temperature and/or fish presence on the final size of $E$. serrulatus.

The body-size of $M$. lilljeborgi (the calanoid from FON) varied more than that of $A$. kerkyrensis (the calanoid from AVE) because the first pond is probably a more unstable environment, due to the extreme reduction of its water volume during late summer (and the consequent disappearance of the calanoid population during this period). We must also underline that other species (M. viridis, E. serrulatus) of FON showed a wider relative variation in body-size than the species of AVE (M. gracilis, T. dibowski, T. prasinus, E. serrulatus, see Tab. 3). In addition we also noted that the calanoid clutch size was more variable in FON. As a consequence, it can be surmised that the variability range of the studied phenotypes is associated with the instability of the environment, and our intent is to clarify this association in the future.

\section{ACKNOWLEDGMENTS}

The authors would like to express their gratitude to Nicoletta Riccardi (CNR Verbania-Pallanza) and Giampaolo Rossetti (University of Parma) for useful comments on the first draft of the present work. The Corpo Forestale dello Stato (Forest Guards) gave us fruitful assistance during sample collection. Fabio Stoch (Ministry of Environment of the Italian Government) guided us in the correct identification of selected material, and Salvatore Martorano (Official Guide of the Pollino National Park) showed us ponds unknown on official maps.

\section{REFERENCES}

Adler, G. \& P. Jaspersen. 1920. Variationss saisonnieres chez quelques copepodes planktoniques marins. Meddr. Komm. Danm. Fiskoq. Havunders. Ser. plankton, 2: 1-46.

Alexeev, V.R. 1990. Diapausa rakoobrasnik. Ecologo fisiologicheskie aspekti. Nauka Moskva: 144 pp. (in Russian).

Atkinson, D. 1994. Temperature and organism size - a biological law for ectotherms? Adv. Ecol. Res., 25: 1-58.

Atkinson, D. \& R.M. Sibly. 1997. Why organism are usually bigger in colder environments? Making sense of a life history puzzle. Trends in Ecology \& Evolution, 12(6): 235-239.

Dussart, B. 1967. Les Copepodes des eaux continentales d'Europe occidentale. I. Calanoides et Harpacticoides. Ed. Boubée \& Cie, Paris: 500 pp.

Dussart, B. 1969. Les Copepodes des eaux continentales d'Europe occidentale. II. Cyclopoïdes et biologie. Ed. Boubée \& Cie, Paris: $292 \mathrm{pp}$.

Dussart, B. 1989. Crustacés Copépodes Calanoides des eaux interieures africanes. Crustaceana, Supplement 15: 206 pp.

Elster, H.J. 1936. Einige biologissche Beobachtungen a Heterocope borealis FISCHER ( $H$. weismanni Imhof). Int. Rev. Hydrobiol., 33: 357-433.

Elster. H.J. 1954. Über die Populationsdynamik von Eudiaptomus gracilis Sars und Heterocope borealis im Bodensee-Obersee. Arch. Hydrobiol., Suppl. 20: 546-614.

Galbraith, M.G.Jr. 1966. Size-selective predation on Daphnia by raibow trout yellow perch. Trans. Am. Fish. Soc., 96: 110.

Gauthier, H. 1928. Recherches sur la faune des eaux continentals de l'Algerie et de la Tunisie. Imp. Minerva, Alger: $416 \mathrm{pp}$.

Hutchinson, G.E. 1951. Copepodology for the Ornithologist. Ecology, 32(3): 571-577. 
Hutchinson, G.E. 1967. A treatise on Limnology. Vol II. Introduction to lake biology and the limnoplankton. II. John Wiley \& Sons, Inc. New York: 1115 pp.

Jeppesen, E., J.P. Jensen, M. Søndergaard, T. Lauridsen \& F. Landkildehus. 2000. Trophic structures, species richness and species diversity in Danish lakes: changes along a phosphorus gradient. Freshwat. Biol., 45: 201-218.

Jersabeck, C.D., A. Brancelj, F. Stoch \& R. Schabetsberger. 2001. Distribution and ecology of copepods in mountain of the Eastern Alps. Hydrobiologia, 453/454: 309-324.

Karjalainen, J., M. Rahkola, A.L. Holopainen, T. Huttula, J. Jurvelius, M. Viljanen, V. Avinski, G. Letanskaia \& I. Telesh. 1999. Trophic gradients and associated changes in the plankton communities in two bays of Lake Ladoga. Boreal Env. Res., 4: 229-238.

Licchelli, C., D. Presta, G. Alfonso, S. Moscatello \& G. Belmonte. 2003. Prima segnalazione in Italia di Arctodiaptomus kerkirensis (Crustacea Copepoda Calanoida). Riv. Idrobiol., 42(1-3): 283-293.

Manca, M. \& M. Armiraglio. 2002. Zooplankton of 15 lakes in the Southern Central Alps (pre-ca 1850 AD) communities. J. Limnol., 61(2): 225-231.

Margaritora, F.G. 1990. Influenza di Gambusia affinis sulla struttura e dinamica dei popolamenti zooplanctonici degli stagni di Castel Porziano (Lazio). Riv. Idrobiol., 29(3): 747-762.

Margaritora, F.G., M. Bazzanti, O. Ferrara, L. Mastrantuono, M. Seminara \& D. Vagaggini. 2003. Classification of the ecological status of volcanic lakes in Central Italy. $J$. Limnol., 62(Suppl. 1): 49-59.

Margaritora, F.G., D. Corsetti, M. Gigli \& F. Lombardi. 1981. Prime osservazioni sulla struttura e distribuzione delle biocenosi di un laghetto carsico: il Lago Superiore di Percile (Lazio). Riv. Idrobiol., 20: 673-687.

Margaritora, F.G. \& M.C. Roberti. 1995. Analisi e struttura dei popolamenti di due bacini astatici della tenuta di $\mathrm{Ca}-$ stel Porziano (Lazio) con particolare riferimento alla successione dello zooplancton. Riv. Idrobiol., 34: 1-14.

Margaritora, F.G. \& M.C. Usai. 1983. Osservazioni faunistico-ecologiche su un laghetto d'alta quota dell'Appennino Abruzzese: il Lago di Campo Felice. Riv. Idrobiol., 22(2-3): 159-167.

Marrone, F. \& L. Naselli-Flores. 2004. First record and morphological features of Hemidiaptomus (Occidodiaptomus) ingens (Guerney, 1909) (Copepoda Calanoida) in Italy. $J$. Limnol., 63(2): 250-255.

Mastrantuono, L. 1981. Diversità morfologica e variazioni temporali di Cyclops abyssorum Sars (Crustacea Copepoda) nei laghi di Nemi e Bracciano. Riv. Idrobiol., 20(2): 469-484.

Mastrantuono, L. 1991. Contributo alla conoscenza dei ciclopoidi (Crustacea Copepoda) di acque temporanee del Lazio (Tenuta di Castelporziano, Parco Nazionale del Circeo): composizione, distribuzione e confronto coi dati dell'Italia Centro-Meridionale. Riv. Idrobiol., 30(2-3): 283295

Mauchline, J. 1998. The Biology of Calanoid Copepods. Advanced in Marine Biology, 2: 398-399.

McNaugh, D.C. 1975. A hypothesis to explain the succession from calanoids to cladocerans during eutrophication. Verh. Internat. Verein. Limnol., 19: 724-731.
Naselli-Flores, L., Barone R. \& M. Zunino. 1998. Distribution patterns of freshwater zooplankton in Sicily (Italy). Verh. Internat. Verein. Limnol., 26: 1973-1980.

Patalas, K. 1972. Crustacean plankton and the eutrophication of St. Laurence Great Lakes. J. Fish. Res. Bd Canada, 29: 1451-1462.

Ranga Reddy, Y. 1994. Copepoda: Calanoida: Diaptomidae. Guide to the identification of the microinvertebrates of the continental waters of the world, 5. Academic Publishing: $221 \mathrm{pp}$.

Ravera, O. 1996. Zooplankton and trophic state relationships in temperate lakes. Mem. Ist. ital. Idrobiol., 54: 195-212.

Ravera, O. \& V. Tonolli. 1956. Body Size and number of eggs in Diaptomids, as related to water renewal in mountain lakes. Limnol. Oceanogr. 1(2): 118-122.

Rossetti, G., S. Sei, G. Paris \& I. Ferrari. 1995. Ciclo vitale di Eudiaptomus intermedius (Copepoda, Calanoida) in un lago Appenninico d'alta quota (Lago Scuro Parmense). Atti Società Italiana di Ecologia, 16: 471-473.

Rossi, V., G. Paris, G. Rossetti, S. Sei \& P. Viaroli. 1992. Analisi di popolazioni del copepode calanoide Mixodiaptomus kupelwieseri in corpi d'acqua dell'Appennino Ligure. Atti $10^{\circ}$ Congr. AIOL, Alassio, 4-6 Novembre 1992: 117-124.

Ruggiero, A., A.G. Solimini \& G. Carchini. 2004. Limnological aspect of an Appennine shallow lake. Ann Limnol. Int. J. Lim., 40 (2): 89-99.

Santer, B. 1998. Life cycle strategies of free-living copepods in fresh waters. J. Mar. Sys., 15: 327-336.

Stella, E. 1961. Biologia e sistematica di Mixodiaptomus kupelwieseri Brehm di pozze temporanee dell'Agro Pontino (Lazio). Mem. Ist. ital. Idrobiol., 13: 51-74.

Stella, E. 1970. Diaptomidi della Sardegna. Istituto Lombardo (Rend. Sc.) B, 104: 69-87.

Stella, E. 1984. Copepoda: Calanoida. XXI Fauna d'Italia. Ed. Calderoni, Bologna: $101 \mathrm{pp}$.

Stoch, F. 2005a. Crustacea Copepoda. In: S. Russo \& F. Stoch (Eds), Checklist e distribuzione della fauna italiana. 10000 specie terrestri e delle acque interne. Ministero dell'Ambiente e della Tutela del Territorio. Verona; 91-95.

Stoch, F. 2005b. Ricchezza di specie e rarità. Analisi della distribuzione in Italia. In: S. Russo \& F. Stoch (Eds), Checklist e distribuzione della fauna italiana. 10000 specie terrestri e delle acque interne. Ministero dell'Ambiente e della Tutela del Territorio. Verona; 33-35.

Tavernini, S., E. Fratta, F. Sartore, \& G. Rossetti. 2003. Distribution and ecology of calanoid species in relation to morphometric and chemical characteristics of lakes and ponds of the northern Appennines (Italy). J. Limnol., 62(1): 28-34.

Tonolli, V. 1947. Gli alti laghi della Val Bognanco. Parte I. Mem. Ist. ital. Idrobiol., 3: 187-269.

Von Bertalanffy, L. 1960. Principles and theory of growth. In: W.W. Nowinski, (Ed.), Fundamental Aspects of Normal and Malignant Growth. Elsevier, Amsterdam: 137-259.

Williams-Howze, J. 1997. Dormancy in the free-living copepod orders Cyclopoida, Calanoida and Harpacticoida. Oceanogr. Mar Biol. Ann. Rew., 35: 257-321. 